\title{
The effectiveness of biogenic silver nanoparticles in the treatment of caprine mastitis induced by Staphylococcus aureus
}

\author{
A.H. Al Dujaily ${ }^{1}\left(\mathbb{D}\right.$ and A.K. Mahmood $^{2}(\mathbb{D}$ \\ ${ }^{1}$ Department of Veterinary Clinical Sciences, Faculty of Veterinary Medicine, University of Kufa, Kufa, ${ }^{2}$ Department of \\ Internal and Preventive Veterinary Medicine, Faculty of Veterinary Medicine, University of Baghdad, Iraq.
}

\begin{tabular}{l} 
Article information \\
\hline Article history: \\
Received September 07, 2021 \\
Accepted October 29, 2021 \\
Available online December 14, 2021 \\
\hline Keywords: \\
Silver nanoparticle \\
Milk \\
Mastitis \\
Staphylococcus aureus \\
\\
\hline Correspondence: \\
A.H. Al Dujaily \\
alih.aldujaily@uokufa.edu.iq
\end{tabular}

\begin{abstract}
The aim of the present study is to determine the efficiency of silver nanoparticles in mastitis treatment induced by Staphylococcus aureus, 20 lactating goats were infected intramammary inoculated with $1.5 \times 10^{8} \mathrm{cfu} / \mathrm{ml}$ of virulence Staphylococcus aureus isolated from milk of caprine mastitis and at $48 \mathrm{hr}$ post inoculation, the animals were divided randomly into four groups equally, $1^{\text {st }}$ group left without treatment as control positive, $2^{\text {nd }}$ group treated intramammary infusion with $5 \mathrm{ml}$ Silver nanoparticle after $2 \mathrm{~h}$ from infection daily for 3 consecutive days, $3^{\text {rd }}$ group treated intramammary infusion with $5 \mathrm{ml}$ Silver nanoparticle after $72 \mathrm{~h}$ from infection daily for 3 consecutive days, $4^{\text {th }}$ group treated intramammary infusion with $5 \mathrm{ml}$ Silver nanoparticle mixed with gentamycin after $72 \mathrm{~h}$ from infection daily for 3 consecutive days. The silver nanoparticles used in this study were created using a green method from Bacillus clausii. The Scanning electron microscope was spherical and homogeneous form, with a size range of 25 to $45 \mathrm{~nm}$. Results showed severe clinical signs of the mammary gland with heavy bacterial isolation in 1st control groups at 3,6-, 9-, 14- and 21-days post infection, while animals that were intramammary treated with Silver nanoparticle alone or combination with gentamycin showed a disappearance in clinical signs of the mammary gland and bacterial isolation, it was concluded that Silver nanoparticle had a strong action against mastitis caused by Staphylococcus aureus.
\end{abstract}

DOI: 10.33899/ijvs.2021.131415.1946, (CAuthors, 2021, College of Veterinary Medicine, University of Mosul.

This is an open access article under the CC BY 4.0 license (http://creativecommons.org/licenses/by/4.0/).

\section{Introduction}

Mastitis is an infection of the mammary gland parenchyma that may inflict partial or total damage to the gland. It's marked by a variety of physical and chemical differences in milk, as well as pathological changes in the glandular tissue. Mastitis in goats is generally classified as either subclinical (asymptomatic) or clinical (symptomatic) depending on etiopathological findings and observations; acute, subacute, chronic, and gangrenous (1). Several pathogens can cause mastitis, but $S$. aureus is the most commonly diagnosed causal microorganism of intra mammary infection (IMI) in goats. However, S. aureus infection in the mammary gland warrants particular consideration due to the carriage of various virulence factors for this bacterium causes both acute CM (gangrenous mastitis) and SCM in lactating goats (2). S. aureus typically colonizes the teat opening or cracked teat skin. The ability of $S$. aureus to produce extremely toxic compounds that damage mammary gland membranes. Intramammary infection caused by $S$. aureus in dry period persists during lactation and may pose a potential risk to human health not only because of the risk of transmission of pathogens, but also because of the presence of enterotoxins in milk or milk products especially in goats' milk (3).

Antibiotics are widely used to treat microorganisms associated with mastitis in dairy goats, but it is well 
recognized that continued use of these chemical agents facilitates antibiotic resistant in bacterial communities (4). Multidrug-resistant (MDR) mastitis pathogens, particularly methicillin-resistant staphylococcal strains, are therefore considered a well-documented threat to the production of dairy goats, so treatment that is not successful in the case of mastitis has serious economic effects for the country and for livestock farmers (5). Due to the rise in multidrugresistant infections, researchers revealed that AgNPs had broad range antimicrobial activity, killing over 650 distinct pathogens including viruses, bacteria, parasites, fungus, and molds (6).

AgNPs have been widely employed in a number of disciplines, including antibacterial medicines, chemotherapy, biomarkers, cell labels, and drug delivery systems for the treatment of various diseases, since they operate as a transporter for many compounds (7).

In Iraq, contaminated animal food origins are common due to unsanitary conditions in slaughtered animals and milking processing, posing a risk to health consumers. There has been no research into treating mastitis induced by $S$. aureus in vivo using AgNPs alone or combination with other antimicrobials. However, this is the first study to investigate the efficacy of AgNPs in the treatment of mastitis lactating goats induced by $S$. auerus in the AlNajaf province, Iraq.

\section{Materials and methods}

The study was conducted at College of Veterinary Medicine, University of Kufa in the year 2021. The silver nanoparticles utilized in this work were produced using a green approach from Bacillus clausii. The Scanning electron microscope (SEM) was used to characterize biosynthesized silver nanoparticles. To prepare intramammary AgNPs, $5 \mathrm{ml}$ of glycerol was mixed with powder AgNPs for manufacturing, or half the amount of AgNPs was coupled with gentamycin and the solution was maintained at room temperature for 2 hours to homogenize.

\section{California mastitis test (CMT) and somatic cell count (SCC)}

Milk samples with CMT scores of 0 , Trace, and 1+ were consider negative, while those with a score of $2+$ or $3+$ were consider positive. The number of somatic cells was counted with a microscope. Positive SCCs were defined as having more than $>1 \times 10^{6}$ cells $/ \mathrm{ml}$ milk $(8,9)$.

\section{Bacterial isolation}

S. auerus was isolated from milk of lactating goats suffering from clinical mastitis during a survey carried out during 2021. Isolation and identification of bacteria from milk samples were performed according to (10). Preliminary identification and characterization were carried out by conservative approaches, for example, colony morphology (golden-yellow pigmented colonies), positive for catalase and coagulase test and those that exhibited hemolytic characters were identified as $S$. aureus strains. All preliminary identified isolates of $S$. aureus were tested by VITEK-2 Compact System (BioMe'rieux, France) according to the procedures provided by the company. The results were finally interpreted and tabulated automatically by the GP-ID library.

\section{Experimental design}

Twenty-five lactating local breed goats were used, weighing $36-45 \mathrm{~kg}$ and ranging in age from 2-5 years in early lactation to mid-lactation, 5 does isolated as a negative control group and 20 of them were inoculated intramammary in the two halves of each female mammary gland with $1 \mathrm{ml}$ contains $1.5 \times 10^{8} \mathrm{cfu} / \mathrm{ml}$ field strain of $S$. aureus isolated from caprine mastitis milk according to (11).

At $48 \mathrm{hr}$ post inoculation all animals were randomly divided into four groups equally as following; the $1^{\text {st }}$ group was left without treatment as the positive control group, the 2ed group was treated intramammary $5 \mathrm{ml}$ AgNPs after $2 \mathrm{~h}$ from infection daily for 3 consecutive days, the 3rd group was treated intramammary with $5 \mathrm{ml}$ AgNPs after $72 \mathrm{~h}$ from infection daily for 3 consecutive days, the 4th group was treated intramammary by preparation of $5 \mathrm{ml}$ AgNPs mixed with gentamicin after $72 \mathrm{~h}$ from infection daily for 3 consecutive days.

The following values were used as disease indicators: CMT: $\geq 1+$ and SCC: $>1 \times 10^{6}(8)$. The microbiology of the experimental infection was tracked from hour 0 to hours 24 , 48, and 72 after infection. Milk samples from infected does' halves and control udder halves were collected and tested for the presence of $S$. aureus using a bacteriological process (10).

The microbiology of the experimental groups was tracked after 3, 6, 9, 14 and 21 days after treatment. The udder teats were sterilized with $70 \%$ ethyl alcohol to collect milk samples. Then, $0.01 \mathrm{ml}$ of each milk sample was cultured on Mannitol salt agar. The cultures were incubated at $37^{\circ} \mathrm{C}$ for 24 hours. Finally, yellow colonies were initially identified as $S$. aureus by Gram staining as well as catalase, DNase and coagulase tests $(10,12)$.

\section{Statistical analysis}

The data collected were analyzed using SPSS version 26. Differences between groups were determined using the least significant differences test (LSD). One-way ANOVA was used to do statistical analysis of variance on the data.

\section{Results}

\section{Characterization of Sliver nanoparticles}

The SEM had a spherical and homogenous shape, and its size varied from 25 to $45 \mathrm{~nm}$. The size of the AgNPs as 
determined by X-ray diffraction (XRD) was $50 \mathrm{~nm}$. To test for the presence of elemental silver, Energy dispersive spectroscopy (EDS) was employed. The Atomic force microscope (AFM) revealed the three-dimensional structure of silver nanoparticles, which had an average diameter of $47.18 \mathrm{~nm}$.

\section{Clinical signs}

Physical examinations of animals were performed after $S$. aureus inoculation in four groups and compared to negative control groups. Four groups of goats were shown to be hyperthermic. Heart rates were slightly elevated and respiratory rates were higher as compared to negative control groups (Table 1).

On the other hand, the result showed severe clinical symptoms of inflammation in the infected udder halves of five goat groups had skin that felt warm to the touch, swollen, painfulness, hyperemic, and had a gradual decline in milk production. These modifications were present to a lesser degree on hour 24 , but were distinctly visible on hours 48 and 72 after infection. The milk samples collected showed changes in milk appearance (particularly the appearance of visible clots), which first appeared at post infection hour 48 and became more common at hour 72 (Table 2).

Table 1. Clinical examination values of healthy and infected goats; ranges and means \pm SE.

\begin{tabular}{lccccc}
\hline Parameters & G - & GI & GII & GIII & GIV \\
\hline Temperature $\left({ }^{\circ} \mathrm{C}\right)$ & $38.9 \pm 0.2^{\mathrm{B}}$ & $41.6 \pm 0.3^{\mathrm{A}}$ & $39.2 \pm 0.1^{\mathrm{B}}$ & $41.2 \pm 0.3^{\mathrm{A}}$ & $40.6 \pm 0.2^{\mathrm{A}}$ \\
Respiratory (rate/minute) & $24.0 \pm 0.7^{\mathrm{B}}$ & $36.6 \pm 1.6^{\mathrm{A}}$ & $24.4 \pm 0.6^{\mathrm{B}}$ & $38.4 \pm 0.9^{\mathrm{A}}$ & $36.2 \pm 1.6^{\mathrm{A}}$ \\
Heart (rate/minute) & $79.0 \pm 0.8^{\mathrm{B}}$ & $93.4 \pm 2.2^{\mathrm{A}}$ & $80.4 \pm 0.8^{\mathrm{B}}$ & $95.2 \pm 3.0^{\mathrm{A}}$ & $93.0 \pm 2.7^{\mathrm{A}}$ \\
\hline
\end{tabular}

The differences in capital letters horizontally refer to the presence of significant value at $\mathrm{P}<0.05$.

Table 2: Clinical manifestations of mastitis in the negative control and experimental study groups

\begin{tabular}{lccc}
\hline Notation & Systemic signs & Milk appearance & Udder signs \\
\hline Control groups (-) & No systemic reaction & Normal & No visible disease signs \\
Experiment groups (After 24h) & Slight fever & Small clots & Slight swelling \\
Experiment groups (After 48h) & Feverish & visible clots & Swollen \\
Experiment groups (After 72h) & Slightly depressed & Large fibrin clots & Sore, hardened pain \\
\hline
\end{tabular}

Our results reveal the positive control animals have severe clinical signs of inflammation in the infected mammary gland at 3, 6, and 9 days after infection, and these lesions become very severe at 14 days after infection, and the intensity of inflammation in positive control animals is significantly higher than $3 \mathrm{ed}$ and 4 th groups treated intramammary with $5 \mathrm{ml} \mathrm{AgNPs}$ after 6 days of intramammary treatment. When compared to the 3rd group, the 4th group treated intramammary with $5 \mathrm{ml} \mathrm{AgNPs}$ in conjunction with gentamycin demonstrated a quicker disappearance of clinical indications of inflammation (Figure 1). On the other hand, the 2ed group, there were no inflammatory changes in the udder when AgNPs was given two hours after the infection.

\section{CMT and SCC}

The occurrence of a CMT score of zero in the udder halves of does in the negative control groups was verified by goat milk test interpretations. In contrast, 48 hours after pathogen inoculation, the CMT caused a high positive (3+ score) response in all four testing groups. CMT findings in the 3ed and 4th group treated with AgNPs were negative in 9, 14 and 21 day. A significant increase in SCC was observed based on a $3+$ CMT score at 48 hours after $S$. aureus infusion in all infected groups, equating to an SCC >
$5,000,000$ cells $/ \mathrm{ml}$. The SCC outcome in the 3 ed and 4 th groups following AgNPs treatment is a steady reduction after 3, 6-, 9-, 14- and 21-days (Table 3).

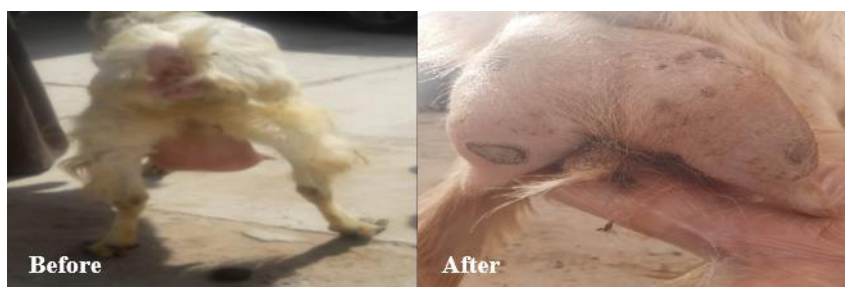

Figure 1: udder goat before and after treatment.

\section{Bacterial isolation}

The microbiological monitoring of the experiment showed that $S$. aureus was reisolated in the respective udder halves of both goats on hours 24, 48, and 72 after its intramammary inoculation. The results revealed significant bacterial isolation from the mammary glands of control positive animals post infection, while no bacterial isolation was reported in the mammary glands of the $2^{\text {nd }}$ and $3^{\text {rd }}$ groups were treated intramammary with AgNPs, also, $4^{\text {th }}$ group treated intramammary AgNPs combined with gentamycin. 
Iraqi Journal of Veterinary Sciences, Vol. 35, Supplement III, 2021 (73-78)

Proceedings of the 13th (2nd International) Scientific Conference, College of Veterinary Medicine, University of Baghdad

Table 3: Somatic cell count results of lactating goats

\begin{tabular}{lccccc}
\hline Days & Control (-) & Group I & Group II & Group III & Group IV \\
\hline 0 day Before infection & $923.1 \pm 18.1^{\mathrm{A}}$ & $850.8 \pm 46.9^{\mathrm{A}}$ & $879.6 \pm 27.0^{\mathrm{A}}$ & $842.4 \pm 25.0^{\mathrm{A}}$ & $901.0 \pm 45.4^{\mathrm{A}}$ \\
3 days after infection & $912.1 \pm 38.1^{\mathrm{B}}$ & $5900.0 \pm 394.2^{\mathrm{A}}$ & $821.2 \pm 55.5^{\mathrm{B}}$ & $6276.4 \pm 507.3^{\mathrm{A}}$ & $6036.0 \pm 456.7^{\mathrm{A}}$ \\
3 days after treatment & $932.1 \pm 25.2^{\mathrm{B}}$ & $7046.0 \pm 305.9^{\mathrm{A}}$ & $921.2 \pm 22.6^{\mathrm{B}}$ & $8077.3 \pm 351.8^{\mathrm{A}}$ & $7745.3 \pm 452.2^{\mathrm{A}}$ \\
6 days after treatment & $949.7 \pm 21.5^{\mathrm{B}}$ & $7710.2 \pm 551.9^{\mathrm{A}}$ & $936.6 \pm 24.3^{\mathrm{B}}$ & $6537.4 \pm 382.7^{\mathrm{A}}$ & $6341.4 \pm 546.2^{\mathrm{A}}$ \\
9 days after treatment & $938.7 \pm 24.2^{\mathrm{D}}$ & $8718.2 \pm 548.6^{\mathrm{A}}$ & $930.3 \pm 17.6^{\mathrm{D}}$ & $6621.4 \pm 430.1^{\mathrm{B}}$ & $4049.4 \pm 206.5^{\mathrm{C}}$ \\
14 days after treatment & $915.9 \pm 38.3^{\mathrm{C}}$ & $10258.2 \pm 215.6^{\mathrm{A}}$ & $878.6 \pm 22.3^{\mathrm{C}}$ & $1818.1 \pm 42.7^{\mathrm{B}}$ & $1699.0 \pm 56.7^{\mathrm{B}}$ \\
21 days after treatment $^{\mathrm{B}}$ & $883.8 \pm 36.5^{\mathrm{B}}$ & $10848.2 \pm 286.4^{\mathrm{A}}$ & $818.6 \pm 18.6^{\mathrm{B}}$ & $803.3 \pm 14.5^{\mathrm{B}}$ & $767.0 \pm 25.1^{\mathrm{B}}$ \\
\hline
\end{tabular}

The differences in capital letters horizontally refer to the presence of significant value at $\mathrm{P}<0.05$. $(n=30)$; means $\left(\times 10^{3}\right) \pm \mathrm{SE}$.

\section{Discussion}

The most common bacterial genus in goat mastitis is Staphylococcus, and the severity of infections caused by $S$. aureus in different types of mastitis is related to its virulence factors, which allow it to adhere to the surface, invade or avoid the immune system, and cause harmful toxic effects to the host (13). Severe clinical mastitis with systemic signs induced by $S$. aureus was most likely caused by the activity of various cytotoxins, which caused significant tissue damage and a systemic reaction in the animal (1,3). Microorganisms cause alterations in mammary tissue by creating toxins that disrupt cell membranes, causing damage to milk producing tissue, while others may enter and grow within the epithelium before causing cell death, and in these cases, mastitis is defined by the influx of somatic cells. Under these conditions, the acini and afflicted ducts begin to involute, resulting in the cessation of milk production (14). The CMT produced a strong positive $(3+$ score $)$ response in all experiment goats 48 hours after pathogen inoculation. The increased CMT score largely represents the movement of neutrophils from the blood into glandular secretion in response to infection. As a result, there is agreement with (15).

The SCC has been widely used to assess the inflammatory status of the mammary glands of goats. In the current study, SCC in goat's milk were utilized to test the in vivo effectiveness of AgNPs in treating $S$. aureus mastitis, and a good connection was discovered between high milk SCC and pathogen persistence in the mammary gland. SCC levels in milk were high during the first few days after infection and then gradual decreased after intramammary treatment. As a result, SCC appear to be useful in predicting the infectious state of the udder (16).

However, S. aureus colonies were completely absent in the milk culture of goats after infusing the udder with AgNPs. This might indicate that AgNPs include an antibacterial agent capable of killing $S$. aureus that exists extracellularly or intracellularly inside the caprine mammary glands. The absence of $S$. aureus in the milk following treatment with AgNPs by intramammary infusion of infected goats may indicated that AgNPs fully destroys the bacterium as a result of high concentrations of AgNPs entering the bacterial cells. The main force that facilitated adhesion between AgNPs and bacterial cell membrane is electrostatic attraction between the positive charge of AgNPs and the negative charge of bacterial cells. This interaction causes the bacterial cytoplasm to shrink and the membrane to detach, resulting in the rupture of the bacterial cell wall (17).

Also, silver ions' attachment to protein sulfur groups in the bacterial cell wall causes its disruption and impairs the transmission of phosphate ions and potassium ions across the microbial cell membrane as a result of increased cellular permeability, which results in the loss of bacterial cell components such as proteins, sugars, and ATP depletion (18), and impairment of the respiratory electron transport chain by inactivated respiratory chain enzymes (19); furthermore, AgNPs induce condensation of DNA in bacterial cells, resulting in bacterial cell death and necrosis (6).

Moreover, increased cellular accumulation of AgNPs resulted in oxidative stress (20), which is thought to be one major mechanism by which AgNPs kill bacteria by causing oxidative DNA damage and preventing bacterial reproduction (21).

On the other hand, the current results showed that treatment with AgNPs combined with gentamycin resulted in full recovery with absence of $S$. aureus isolation in the mammary glands of infected goats. These results may indicate that synergistic action between AgNPs and gentamycin drug, as these particles can be facilitated action of these antibiotics. Gentamicin is a protein synthesis inhibitor. Gentamicin inhibits protein synthesis by permanently binding the $30 \mathrm{~s}$ subunit of the bacterial ribosome; the combination action of AgNPs and gentamicin was particularly effective against $S$. aureus. The precise method of action is currently being researched; however various possibilities have been postulated. It has been reported that, when compared to AgNPs alone, the combination of antibiotic with AgNPs complexes releases $\mathrm{Ag}^{+}$at a higher rate; additionally, it has been proposed that the combination of antibiotic with AgNPs via the active groups of antibiotics such as hydroxyl group and amine group results in conjugation of both molecules. This will 
result in an increase in the effective concentration of antibiotic at a specific location (22).

Many researchers reported the idea of combining antibiotics with AgNPs, which revealed that the hydroxyl and amino groups of antibiotics may easily bind with AgNPs, enhancing the interaction of these antibiotics with bacterial cells and implying that AgNPs may function as antibiotic carriers as well as increase the effective concentration of antibiotic at a specific site (23).

Finally, it was discovered that all experimental animals treated with nano-silver were in good condition, including the absence of clinical symptoms of udder inflammation and no change in the physical characteristics of milk and milk production. These findings are consistent with recent research, which indicates that AgNPs have low toxicity for mammary gland tissue and thus should not have a negative impact on udder tissues (24). Nonetheless, the most essential benefit of NPs is that they do not cause bacterial resistance (6), which is presently the most serious problem in the treatment of bacterial mastitis.

\section{Conclusion}

A strain of $S$. aureus isolated from clinical mastitis was extremely sensitive to AgNPs, especially when coupled with an antibiotic (gentamycin). AgNPs exhibit in vivo characteristics that appear to expedite mastitis cure while having no effect on animal health, udder, or milk production. AgNPs may be formulated in a suitable intramammary applicator and utilized to treat clinical and subclinical mastitis in goats caused by $S$. aureus.

\section{Acknowledgements}

The researchers would like to thank the staff of AlNajaf Veterinary Teaching Hospital for the initial diagnosis and sample collection, as well as thanks to all the workers in the diagnostics laboratory at the University of Kufa, Faculty of Veterinary Medicine.

\section{Conflicts of interests}

There are no conflicts of interest declared by the authors.

\section{References}

1. Radostitis OM, Gay CC, Hinchcliff KW, Constable PD. Veterinary medicine. $10^{\text {th }}$ ed. Edinburgh: Saunders Co;2007. 2047-2050 p. [available at]

2. Rainard P, Gitton C, Chaumeil T, Fassier T, Huau C, Riou M, Martin P. Host factors determine the evolution of infection with Staphylococcus aureus to gangrenous mastitis in goats. Vet Res. 2018;49(1):1-17. DOI: 10.1186/s13567-018-0564-4

3. Abdelrahman MA, Khadr AM, Mahmoud AA, Elsheimy TM, Osman A. Occurrence of clinical and subclinical mastitis and associated risk factors in lactating goats with special reference to dry period infection and teat skin microflora. Alexandria J Vet Sci. 2020;64(2):1-4. DOI: 10.5455/ajvs. 28648

4. Sheet OH. Isolation of Staphylococcus aureus from ruminant's milk and their resistance to antibiotics in Ninevah governorate. Iraqi J Vet Sci. 2010;24(2):109-114. DOI: $10.33899 / \mathrm{ijvs} .2010 .5586$

5. Unny NM, Pillai UN, Mani BK. Biofilm associated staphylococcal mastitis in goats. Int $\mathbf{J}$ Livestock Res. 2020;10(6):1-2. DOI: 10.5455/ijlr.20200414025108

6. Rai MK, Deshmukh SD, Ingle AP, Gade AK. Silver nanoparticles: The powerful nanoweapon against multidrug-resistant bacteria. J Applied Microbiol. 2012;112(5):841-852. DOI: 10.1111/j.13652672.2012.05253.x

7. Al-Baker A, AlKshab AA, Ismail HK. Effect of silver nanoparticles on some blood parameters in rat. Iraqi J Vet Sci. 2020;34(2):389-395. DOI: $\underline{10.33899 / \text { ijvs.2020.165812 }}$

8. Souza FN, Blagitz MG, Penna CFAM, Della Libera AMMP, Heinemann MB, Cerqueira, MMOP. Somatic cell count in small ruminants: friend or foe? Small Ruminant Res. 2012;107(2-3):65-75. DOI: $10.1016 /$ j.smallrumres.2012.04.005

9. Sadoon AS. Clinical and subclinical mastitis in buffalue in Mosul area, Iraq. Iraqi J Vet Sci. In Press. 2021. DOI: 10.33899/ijvs.2021.129644.1671

10. Quinn PJ, Carter ME, Markey B, Carter GR. Clinical Vet Microbiol. Mosby Pub Co;2004. 237-242 p.

11. Fasulkov I, Karadaev M, Vasilev N, Simeonov R, Urumova V, Mladenova E. Ultrasound and histopathological investigations of experimentally induced Staphylococcus aureus mastitis in goats. Small Ruminant Res. 2015;129:114-120. DOI: 10.1016/j.smallrumres.2015.05.018.

12. Sheet OH, Jwher DM, Al-Sanjary RA, Alajami AD. Direct detection of Staphylococcus aureus in camel milk in the Nineveh governorate by using the PCR technique. Iraqi J Vet Sci. 2021;35(4):669-672. DOI: 10.33899/ijvs.2020.127725.1524.

13. Akkou M, Bentayeb L, Ferdji K, Medrouh B, Bachtarzi MA, Ziane H, Tazir M. Phenotypic characterization of Staphylococci causing mastitis in goats and microarray-based genotyping of Staphylococcus aureus isolates. Small Ruminant Res. 2018;169:29-33. DOI: org/10.1016/j.smallrumres.2018.10.015.

14. Da Silva E R, do Carmo LS, Da Silva N. Detection of the enterotoxins A, B, and C genes in Staphylococcus aureus from goat and bovine mastitis in Brazilian dairy herds. Vet Microbiol. 2005;106(1-2):103107. DOI: $10.1016 /$ j.vetmic.2004.12.005

15. Zhao X, Lacasse P. Mammary tissue damage during bovine mastitis: Causes and control. J Animal Sci. 2008;86(13):57-65. DOI: 10.2527/jas.2007-0302

16. Peixoto RDM, Araújo RDMP, Reges AM, Alves APP, Pinheiro JW, Mota RA, Costa MMD. Indirect diagnostic tests for the detection of subclinical mastitis in dairy goats experimentally infected with Staphylococcus aureus. Ciencia Rural. 2016;46(7):1217-1222. DOI: 10.1590/0103-8478cr20150507

17. Dakal TC, Kumar A, Majumdar RS, Yadav V. Mechanistic basis of antimicrobial actions of silver nanoparticles. Frontiers Microbiol. 2016;7:1831. DOI: 10.3389/fmicb.2016.01831

18. Li J, Rong K, Zhao H, Li F, Lu Z, Chen R. Highly selective antibacterial activities of silver nanoparticles against Bacillus subtilis. J Nanosci Nanotechnol. 2013;13(10):6806-6813. DOI: 10.1166/jnn.2013.7781

19. Belluco S, Losasso C, Patuzzi I, Rigo L, Conficoni D, Gallocchio F, Ricci A. Silver as antibacterial toward Listeria monocytogenes. Frontiers Microbiol. 2016;7:307. DOI: 10.3389/fmicb.2016.00307.

20. Wu D, Fan W, Kishen A, Gutmann JL, Fan B. Evaluation of the antibacterial efficacy of silver nanoparticles against Enterococcus faecalis biofilm. J Endodont. 2014;40(2):285-290. DOI: 10.1016/j.joen.2013.08.022

21. Rinna A, Magdolenova Z, Hudecova A, Kruszewski M, Refsnes M, Dusinska M. Effect of silver nanoparticles on mitogen-activated protein kinases activation: role of reactive oxygen species and 
implication in DNA damage. Mutagenesis. 2015;30(1):59-66. DOI: 10.1093/mutage/geu057

22. Rajora N, Kaushik S, Jyoti A, Kothari SL. Rapid synthesis of silver nanoparticles by Pseudomonas stutzeri isolated from textile soil under optimised conditions and evaluation of their antimicrobial and cytotoxicity properties. IET Nanobiotechnol. 2016;10(6):367-373. DOI: 10.1049/iet-nbt.2015.0107

23. Katva S, Das S, Moti HS, Jyoti A, Kaushik S. Antibacterial synergy of silver nanoparticles with gentamicin and chloramphenicol against Enterococcus faecalis. Pharmacogn Mag. 2017;13(4):S828. DOI: 10.4103\%2Fpm.pm $120 \quad 17$

24. Jagielski T, Roeske K, Bakuła Z, Piech T, Wlazlo L, Bochniarz M, Krukowski H. A survey on the incidence of Prototheca mastitis in dairy herds in Lublin province, Poland. J Dairy Sci. 2019;102(1):619628. DOI: $\underline{10.3168 / \mathrm{jds} .2018-15495}$

\section{فعالية جسيمات الفضة النانوية المنتجة حيوياً

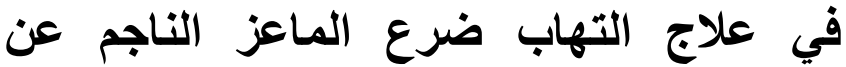 المكور علات العنقودية الأهبية.}

علي حسين الاجيلي' و علاء كامل محمود'

'فرع علوم الطب البيطري، كلبة الطب البيطري، جامعة الكوفة،

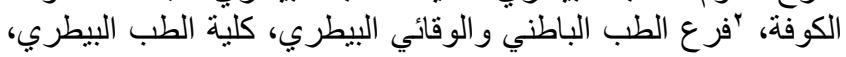

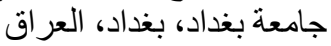

الخلاصة

هدفت الدراسة لتحديد كفاءة جسيمات الفضة النانوية في علاج

التهاب الضرع الناجم عن المكورات العنقودية الذهبية، تم استحداث

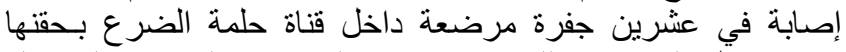

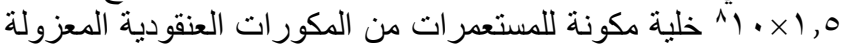

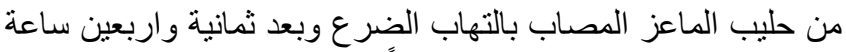

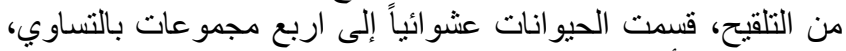
المجموعة الأولى تركت دون علاج كمجموعة سيطرة إيجابية،

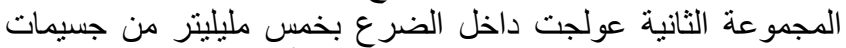
الفضة النانوية بعد ساعتين من الإصابة بومياً لمدة ثناثنة أيام متتالية،

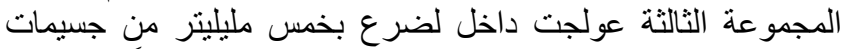

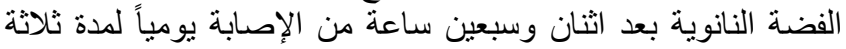

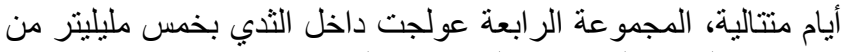

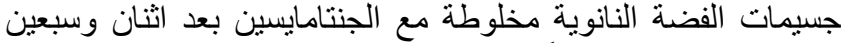

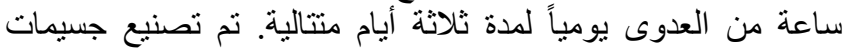

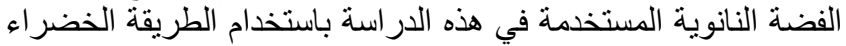

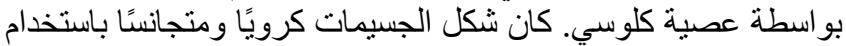

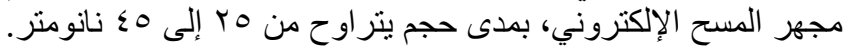

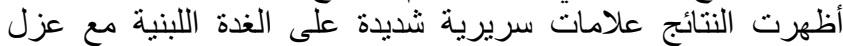

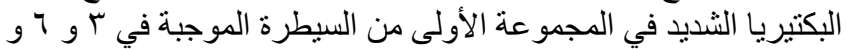

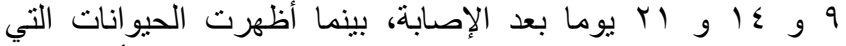
عولجت داخل الضرع مع جسيمات الفضة النانوية وحدها أو بخلطها

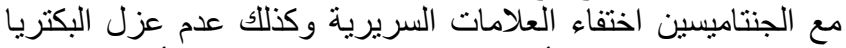

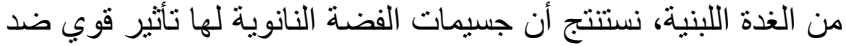
التهاب الضرع في الماعز والذي تسببه المكور ات العنقودية الذهبية. 